\title{
Chrystocentryczne głoszenie zasad życia chrześcijańskiego
}

Ambona jest miejscem przekazywania treści wiary oraz prowadzenia wiernych do udziału w tajemnicy Chrystusa, co powinno być związane $\mathrm{z}$ wewnętrzną przemianą słuchaczy słowa Bożego. Wymaga to zmiany sposobu myślenia, burzenia postaw i zachowań niezgodnych z duchem Chrystusa, wywoływania postaw prawdziwie chrześcijańskich i wprowadzenie odnowionego porządku życia moralnego członków wspólnoty.

Zadaniem homilisty jest głoszenie całości zasad życia chrześcijańskiego w kilkuletnim cyklu, a więc to, co należy czynić dla chwały Bożej i zbawienia człowieka (KPK $768 \$ 1)$. Homilia ma pobudzić wiernych do przemiany życia oraz do odpowiedzi na usłyszane słowo Boże. Słowo to jest owocne wtedy, kiedy stosowane jest w praktyce życia codziennego. Dlatego homilia, będąc pokarmem koniecznym dla podtrzymania chrześcijańskiego życia (OWMR 65), ma ukazywać różne możliwości odpowiedzi na Boże wezwanie w codziennym życiu. Słuchacz powinien dowiedzieć się o tym, jak może realizować swoją wiarę we współczesnym świecie. 
Odwołując się do nauczania soborowego, Kongregacja ds. Kultu Bożego i Dyscypliny Sakramentów w Dyrektorium homiletycznym zaznacza, że homilia, będąc „wyjaśnieniem słowa Pisma Świętego, które zostało odczytane, czy też jakiegoś tekstu liturgicznego, winna prowadzić wspólnotę wiernych do czynnego sprawowania Eucharystii, tak «aby przestrzegali w życiu zobowiązań płynących z sakramentu, który z wiarą przyjęli» (KL 10)” (DH 10). Kolejny punkt tego dokumentu zaznacza, że „w najszerszym znaczeniu homilia jest wypowiedzią o tajemnicach wiary i prawidłach życia chrześcijańskiego dopasowaną do szczególnych potrzeb słuchaczy" (DH 11).

Współczesna teologia homiletyczna głosi przekonanie, że całe przepowiadanie powinno być chrystocentryczne, bowiem Bóg najpełniej objawił się w Chrystusie i w Nim dokonuje się zbawienie człowieka i świata. Zasadę chrystocentryzmu przypomina również Benedykt XVI w adhortacji apostolskiej Verbum Domini: „Dla wiernych musi być jasne, że kaznodziei zależy na ukazaniu Chrystusa, który powinien być w centrum każdej homilii” (VD 59). Opracowanie niniejsze podejmuje próbę odpowiedzi na pytania o chrystocentryzm przepowiadania zasad życia chrześcijańskiego i jego biblijne inspiracje.

\section{Chrystocentryzm przepowiadania słowa Bożego}

Chrystocentryzm to pogląd lub postawa, zgodnie z którymi „centralnym punktem odniesienia dla całej rzeczywistości, a zwłaszcza dla człowieka, jest Jezus Chrystus jako Bóg-człowiek"1. Jezus Chrystus, odkupiciel człowieka „jest ośrodkiem wszechświata i historii” (RH 1). Na gruncie teologii, chrystocentryzm oznacza w pierwszym rzędzie postawę lub pogląd, zgodnie z którym w centrum całej rzeczywistości,

1 P. Góralczyk, Chrystocentryzm ewangeliczny, w: Jan Pawet II. Encyklopedia nauczania moralnego, red. J. Nagórny, K. Jeżyna, Radom 2005, s. 98. 
a zwłaszcza egzystencji chrześcijanina, jest Jezus Chrystus jako Bóg i Człowiek ${ }^{2}$.

Zasada chrystocentryzmu przepowiadania jest czymś zrozumiałym, bowiem Chrystus jest pierwszym i ostatnim Słowem, w którym Bóg najpełniej objawił się człowiekowi. On jest „pośrednikiem i pełnią całego objawienia” (KO 2). Treścią przepowiadania kaznodziejskiego mają być głównie czyny Boga dokonane w Chrystusie dla zbawienia człowieka (KO 2, 7, 8, 10; KL 9), słowo Boże zawarte w Piśmie Świętym (KO 21, 24; KL 35, 52; DK 9), misterium paschalne (KL 5, 35; KO 4; KK 5), Chrystus w ujęciu całościowym (KDK 10) 3 . Zbawienie zwiastowane przez Jezusa Chrystusa jest szczytem i centrum Dobrej Nowiny (EN 9).

Treścią nauczania ma być tajemnica Chrystusa, a wszystko inne na tyle, na ile z tą tajemnicą się łączy (CTr 6). Autentyczne głoszenie Chrystusa powinno być: biblijne, eklezjalne, liturgiczno-mistagogiczne, egzystencjalne i eschatologiczne (KK 7, 48; KL 7;

2 Z uwagi na złożoność zagadnienia centralnej roli Chrystusa w ekonomii zbawienia teologia wyróżnia trzy aspekty chrystocentryzmu: przedmiotowy, podmiotowy i formalny. Chrystocentryzm w znaczeniu przedmiotowym polega na tym, że w odwiecznym zamyśle Bóg w Trójcy Osób ześrodkował całą ekonomię zbawczą na osobie Chrystusa. Prawdę o centralnej roli Chrystusa w dziele zbawienia wyraża liturgia w kończącej Modlitwę Eucharystyczną doksologii: „Przez Chrystusa, z Chrystusem i w Chrystusie...", jak również w częstych kadencjach oracji „przez Chrystusa”. Chrystocentryzm w znaczeniu podmiotowym polega na kreowaniu chrystokształtnej postawy duchowej chrześcijanina. Szczytowy moment takiej postawy wyrażają słowa św. Pawła Apostoła: „Teraz już żyję nie ja, ale żyje we mnie Chrystus" (Ga 2, 20). W chrystocentryzmie w znaczeniu formalnym chodzi o koncentrację wszystkich zagadnień teologicznych, zwłaszcza teologiczno-duchowych, a także antropologicznych i kosmologicznych wokół idei Boga objawiającego się w Jezusie Chrystusie. Chodzi o skupienie wszystkich zagadnień teologicznych oraz antropologicznych wokół idei Boga, objawiającego się w Jezusie Chrystusie. W tym sensie osoba Chrystusa jest również kluczem dla całej teologii. R. Łukaszyk, A. Nossol, Chrystocentryzm, w: Encyklopedia katolicka, t. 3, Lublin 1979, k. 296. M. Chmielewski, Chrystocentryzm, w: Leksykon duchowości katolickiej, red. tenże, Lublin-Kraków 2002, s. 121, 122.

3 L. Szewczyk, Chrystocentryzm w teorii i praktyce przepowiadania słowa Bożego, "Studia Pastoralne" 7 (2011), s. 313. 
KDK 10) ${ }^{4}$. Chrześcijańskie przepowiadanie ma przede wszystkim budzić i utrwalać wiarę chrześcijańską w Chrystusa-Zbawcę oraz próbować udzielać odpowiedzi na mnożące się pytania dotyczące osoby Jezusa Chrystusa ${ }^{5}$.

Papież Franciszek zaznacza, że centrum przepowiadania słowa Bożego i jego istota jest zawsze ta sama: „Bóg, który objawił swoją ogromną miłość w Chrystusie umarłym i zmartwychwstałym. On czyni swoich wiernych zawsze nowymi [...]. Chrystus jest «odwieczną Dobrą Nowiną» (Ap 14, 6) i jest «wczoraj i dziś, ten sam także na wieki» (Hbr 13, 8), ale Jego bogactwo i piękno są niewyczerpane. On jest zawsze młody i jest zawsze źródłem nowości. Kościół nie przestaje być zadziwionym z powodu «głębokości bogactw, mądrości i wiedzy Boga» (Rz 11, 33)” (EG 11). Papież Franciszek stwierdza, że „nie może być autentycznej ewangelizacji bez wyraźnego głoszenia, że Jezus jest Panem", a podstawą głoszenia słowa Bożego w każdej działalności ewangelizacyjnej jest Jezus Chrystus. Absolutnym priorytetem działalności Kościoła powinno być „radosne, cierpliwe i stopniowe przepowiadanie zbawczej śmierci i zmartwychwstania Jezusa Chrystusa" (EG 110) ${ }^{6}$.

Podstawowym zadaniem homilisty jest „ukazywanie słuchaczom pełnego obrazu Chrystusa, wierne przybliżanie jego nauki i dzieła

4 G. Siwek, Przepowiadanie słowa Bożego, w: Teologia pastoralna, t. 2, red. R. Kamiński, Lublin 2002, s. 145-147.

5 W ukazywaniu zagadnień chrystologicznych w przepowiadaniu słowa Bożego należy wskazać „na cztery podstawowe etapy-aspekty, z których każdy może być dodatkowo rozwinięty: przyjście na świat (preegzystencja, obietnica zbawienia, Wcielenie, narodzenie); działalność publiczna (nauczanie, organizacja wspólnoty uczniów, egzorcyzmy, uzdrowienia i wskrzeszenia, czyny prorockie); Pascha (śmierć, zstąpienie do piekieł, zmartwychwstanie, epifanie Zmartwychwstałego, wniebowstąpienie-wywyższenie) oraz obecność w Kościele trwająca do paruzji (zesłanie Ducha Świętego, obecność w Kościele, w słowie i sakramentach, Paruzja)" - G. Strzelczyk, Traktat o Jezusie Chrystusie, w: Dogmatyka, t. 1, red. E. Adamiak, A. Czaja, J. Majewski, Warszawa 2005, s. 414.

6 L. Szewczyk, Treść przepowiadania kaznodziejskiego według adhortacji apostolskiej "Evangelii Gaudium", „Studia Pastoralne" 10 (2014), s. 341-350. 
zbawienia. Kierując się zasadą chrystocentryzmu, kaznodzieja przekaże wiernym główne prawdy wiary i zasady życia chrześcijańskiego oraz wprowadzi ich w święty kult Kościoła. Chrystus nadal wzywa człowieka do naśladowania siebie i zapewnia mu swoją łaskę potrzebną do wypełniania Ewangelii, jest źródłem boskiego światła i zbawczej mocy"7.

\section{Konieczność głoszenia zasad życia chrześcijańskiego}

Przekonanie o konieczności łączenia w życiu chrześcijańskim wiary i postępowania posiada mocne uzasadnienie biblijne. Sam Jezus wypowiada się jednoznacznie: „Jeśli chcesz osiągnąć życie, zachowuj przykazania” (Mt 19, 17); „Nie każdy, który mówi Mi: «Panie, Panie!», wejdzie do królestwa niebieskiego, lecz ten, kto spełnia wolę mojego Ojca, który jest w niebie" (Mt 7, 21). Święty Jakub mocno rozwija wątek dotyczący związku wiary z uczynkami i stawia aktualne w każdym czasie pytanie: „Jaki z tego pożytek, bracia moi, skoro ktoś będzie utrzymywał, że wierzy, a nie będzie spełniał uczynków?", a następnie konkluduje: „Wiara, jeśli nie byłaby połączona z uczynkami, martwa jest sama w sobie" (Jk 2, 14. 17).

Jezus nauczał prawdy o Bogu i człowieku, ale także wskazywał na wynikające z tej prawdy wymogi moralne. Zadaniem współczesnych głosicieli Ewangelii jest nie tylko zapoznanie słuchaczy z wymaganiami nauki Jezusa, zachęta ich traktowania $\mathrm{z}$ całą powagą, ale również zachowywania ich w swoim postępowaniu ${ }^{8}$.

7 J. Twardy, Chrystocentryzm w kaznodziejskiej posłudze słowa, „Śląskie Studia Historyczno-Teologiczne" 40 (2007) z. 1, s. 63.

8 W. Bołoz, Współczesne przepowiadanie moralne i potrzeba uzasadnienia i motywacji, „Homo Dei” 78 (2008) nr 1 (286), s. 20, 21. 
Na taką konieczność wskazuje analiza kulturowo-etyczna współczesnego świata, który w wielu wymiarach jest jeszcze daleko od Ewangelii, zasady życia chrześcijańskiego traktuje jako coś kruchego i zmiennego, a współczesne zjawisko relatywizmu moralnego stało się problemem dla ewangelizacji Kościoła ${ }^{9}$. Również głosicieli słowa Bożego w Polsce czeka konieczność podjęcia refleksji na temat skuteczności głoszenia zasad życia chrześcijańskiego na ambonie.

Według Rafała Boguszewskiego z CBOS w Polsce coraz wyraźniej uwidaczniają się symptomy „sekularyzacji moralności”, która wyraża się w tym, że Polacy w coraz mniejszym stopniu odczuwają potrzebę religijnego uzasadniania własnych postaw moralnych i w wielu kwestiach deklarują poglądy moralne niezgodne $\mathrm{z}$ wyznawaną przez siebie religią. Choć przez większość katolików zasady moralne proponowane przez Kościół katolicki uznawane są za często niezbyt dobrze przystające do dzisiejszej rzeczywistości i wymagające uzupełnienia, to jednak w wielu kwestiach znajdują uznanie i akceptację również osób określających się jako niereligijne lub niewierzące ${ }^{10}$. Obecnie dominuje wybiórcze podejście do moralności katolickiej, a więc takie, które nie przyznaje jej statusu jedynie obowiązującej. Katolickie zasady moralne za najlepsze i wystarczające uznaje jedynie 22 proc. badanych. Największą grupę (42 proc.) stanowią ci, według których zasady moralne katolicyzmu są słuszne, lecz nie ze wszystkimi się zgadzają, a ponadto sądzą, że te, które są słuszne, człowiekowi nie wystarczają. Jedna czwarta ankietowanych (26 proc.) twierdzi natomiast, że wszystkie zasady katolicyzmu są słuszne, jednak wobec

9 Z. Sideł, Pareneza homilijna w polskim przepowiadaniu posoborowym. Studium homiletyczne w świetle „Kazań świętokrzyskich" okresu Wielkiego Postu, mps, rozprawa doktorska, Biblioteka KUL, Lublin 2013, s. 12n.

10 Religijność a zasady moralne. Komunikat z badań CBOS BS5/2014, oprac. R. Boguszewski, Warszawa 2014, s. 16; Przybywa Polaków wybiórczo traktujqcych zasady moralne, http://info.wiara.pl/doc/1873805.Przybywa-Polakow-wybiorczo-traktujacych-zasady-moralne (dostęp: 5.2.2014). 
skomplikowania życia trzeba je uzupełniać jakimiś innymi normami. Moralność religijną za obcą sobie uznaje 10 proc. badanych ${ }^{11}$.

System wierzeń wielu współczesnych chrześcijan zdaje się trafnie opisywać następująca diagnoza: „W modzie nie jest już tradycyjne i logiczne Credo, lecz niejednorodna mieszanka ideowa stworzona na podstawie osobistych preferencji; $w$ modzie nie jest już przestrzeganie tradycji, lecz osobiste upodobania, nie potencjał, lecz pomoc w konkretnych sytuacjach życiowych, nie obowiązujące dogmaty, lecz przeżycie religijne. Kościoły, ich wyznania i ich przekonanie, że prowadzą do prawdy, natrafiają na brak zaufania. Na przypominającą miksturę religię czasów postmodernizmu składa się niewielka ilość miłości bliźniego i duża doza miłości do zwierząt, nieco wędrówki dusz, duża porcja psychologii i parapsychologii, z domieszką ezoteryki, a wszystko dopełnia idylla bożonarodzeniowa i spora doza krytyki Kościoła"12. Stąd konieczna jest refleksja nad tym, co i jak przepowiadać w ramach głoszenia zasad życia chrześcijańskiego. To jednak powinno być poprzedzone refleksją o biblijnych inspiracjach głoszenia zasad chrześcijańskiego życia oraz zróżnicowanym poziomie ortopraksji słuchaczy.

\section{Biblijne inspiracje głoszenia treści moralnych}

Najgłębszy sens i istota biblijnej moralności tkwią w relacji, której pierwotnym ideałem jest harmonia między Bogiem i człowiekiem. Bóg w swojej mowie do człowieka w historii zbawienia systematycznie ujawnia zasady moralne, które zostały ujęte w kategorie religijne. Nie mają one charakteru statycznego, ale podlegają ustawicznemu

11 Zmiany w zakresie wiary i religijności Polaków po śmierci Jana Pawła II, Komunikat z badań CBOS BS/49/2012. Warszawa, kwiecień 2012, s. 21n.

12 P. Neuner, Psychospołeczne i polityczne uwarunkowania chrześcijaństwa dziś, w: Chrześcijaństwo jutra, red. M. Rusecki i in., Lublin 2001, s. 261. 
rozwojowi i dojrzewaniu. Następuje proces rozwoju normatywności moralnej, która jest mentalnie, historycznie i kulturowo uwarunkowanym ludzkim sposobem odczytywania przez człowieka hic et nunc swojej relacji do Boga. Bóg nie tyle objawia zasady moralne, co objawia samego Siebie, jako najpełniejszą miłość, opierając się na pierwotnym założeniu zaufania i zrozumienia w przymierzu ${ }^{13}$. Wydany w 1993 roku dokument Papieskiej Komisji Biblijnej pt. Interpretacja Biblii w Kościele stwierdza:

Orędzie biblijne winno zachować swój główny charakter dobrej nowiny zbawienia ofiarowanej przez Boga. Przepowiadanie dokona dzieła użyteczniejszego i zgodniejszego z Biblią, jeśli najpierw pomoże wiernym „poznać dar Boży” $(J 4,10)$ taki, jaki został objawiony w Piśmie i zrozumieć w sposób pozytywny wymogi, które z niego płyną. ${ }^{14}$

Wydany przez tę samą Komisję w 2009 roku dokument: Biblia a moralność. Biblijne korzenie postępowania chrześcijańskiego precyzuje dokładnie relacje indykatywu zbawczego i imperatywu moralnego ${ }^{15}$ :

[...] moralność, nie będąc elementem drugorzędnym, jest na drugim miejscu. Na pierwszym i zasadniczym miejscu znajduje się inicjatywa Boga, którą wyrazimy teologicznie w terminach daru.

13 S. Jędrzejewski, Moralne implikacje przymierza, "Seminare” 29 (2011), s. 18; L. Stachowiak, Wartości etyczne tradycji o przymierzu, w: Biblia - księga życia Ludu Bożego, red. S. Łach, M. Filipiak, Lublin 1980, s. 20.

14 Papieska Komisja Biblijna, Interpretacja Biblii w Kościele. Dokument Papieskiej Komisji Biblijnej z komentarzem biblistów polskich, red. R. Rubinkiewicz, Warszawa 1999, IV, C, 3.

15 Imperatyw etyczny oznacza konkretne nakazy moralne zawarte w Biblii, natomiast indykatyw zbawczy oznacza zdania opisujące działalność zbawczą Boga lub Chrystusa. J. Kudasiewicz, Cechy specyficzne etosu biblijnego, w: Chrześcijańska duchowość, red. B. Bejze, Warszawa 1981, s. 63-64. 
W perspektywie biblijnej moralność zakorzenia się w uprzednim darze życia, rozumu i wolnej woli (stworzenie), a przede wszystkim w całkowicie darmowym ofiarowaniu uprzywilejowanej wewnętrznej relacji człowieka z Bogiem (przymierze). Nie jest ona na pierwszym miejscu odpowiedzią człowieka, ale odkrywaniem Bożego zamiaru i darem Bożym. Innymi słowy, dla Biblii moralność następuje po doświadczeniu Boga, a dokładniej po doświadczeniu, które Bóg nakazuje człowiekowi przeżywać na mocy całkowicie darmowego daru. Wychodząc z tego punktu, samo Prawo, integralna część procesu przymierza, jest darem Boga. Nie jest ono w punkcie wyjścia pojęciem jurydycznym, nastawionym na zachowania i postawy, ale pojęciem teologicznym, które sama Biblia oddaje najlepiej terminem «droga» (derek po hebrajsku, hodos po grecku): zaproponowana droga. ${ }^{16}$

W przekazie biblijnym tak Starego, jak i Nowego Testamentu nakazy moralne wyprowadzane są zawsze ze zbawczego działania Boga, to znaczy wymagania, które stawia Bóg człowiekowi są zawsze poprzedzone doświadczeniem zbawczego działania. I tak na przykład w Starym Testamencie zobowiązania etyczne dekalogu występują bezpośrednio po historiozbawczym prologu (Wj 20,2), w którym mowa jest o działaniu zbawczym Boga; ta odpowiedź ludu na zbawczy czyn Boga ma charakter wolny (Wj 20, 3-17; Pwt 11, 26-32) ${ }^{17}$. W nauczaniu Jezusa imperatywy moralne były poprzedzone głoszeniem nadejścia królestwa Bożego (Mk 1, 15).

Z przyjściem Chrystusa wypełnił się czas i przybliżyło się panowanie Boga; uzdrowienia chorych, wypędzanie złych duchów, wskrzeszanie umarłych były znakami nadejścia królestwa Bożego

16 Papieska Komisja Biblijna, Biblia a moralność. Biblijne korzenie postępowania chrześcijańskiego, Kielce 2009, nr 4.

17 J. Kudasiewicz, Cechy specyficzne etosu..., dz. cyt., s. 63. 
i zbawienia. Dopiero z rzeczywistości dokonującego się zbawienia wyprowadza Jezus wymagania etyczne: nawrócenie, wiara, miłość i przebaczenie. Doświadczone przez ludzi zbawcze działanie Boga w Chrystusie staje się podstawą ich ludzkich czynów (Mt 18, 23 n; Łk 7, 47). ${ }^{18}$

Uczniowie Jezusa nie pojmowali moralności w sensie wyłącznie normatywnym. W świetle tekstów biblijnych źródłem i pełnią moralności jest sam Bóg, który objawił się w Jezusie Chrystusie ${ }^{19}$.

W podobny sposób zagadnienia moralne ukazane są w nauczaniu apostolskim, które posiada dwa istotne elementy:

pierwszy zawiera to, co Bóg uczynił dla człowieka przez mękę, śmierć i zmartwychwstanie Chrystusa (Dz 2, 22-36; 3, 12-18; 4, 8-12; 10, 37-43); drugi natomiast $z$ tego wydarzenia i obdarowania zbawczego wyprowadza zobowiązania etyczne dla ludzi, a mianowicie nawrócenie, wiarę, przyjęcie chrztu ( $\mathrm{Dz} 2,39-41$;

$3,19-20 ; 10,44-48){ }^{20}$

Jeżeli homilijne głoszenie zasad życia chrześcijańskiego ma być wierne orędziu biblijnemu, to powinno się opierać na schemacie: indykatyw zbawczy $\rightarrow$ imperatyw moralny. Zachęty moralne zawarte $\mathrm{w}$ homilii (imperatyw moralny) powinny być wyprowadzone z orędzia o zbawczym działaniu Boga przez Chrystusa (indykatyw zbawczy) oraz zaproszenia do osobistego przylgnięcia do Niego ${ }^{21}$. Wymagania stawiane człowiekowi przez Boga powinny być zawsze

18 Tamże.

19 S. Jędrzejewski, Moralne implikacje..., dz. cyt., s. 16.

20 J. Kudasiewicz, Cechy specyficzne etosu..., dz. cyt., s. 63.

21 L. Szewczyk, Zagadnienia moralne w wypowiedzi kaznodziejskiej, „Śląskie Studia Historyczno-Teologiczne" 37 (2004) z. 2, s. 51; Z. Sideł, Pareneza homilijna w polskim..., dz. cyt., s. 37. 
poprzedzone doświadczeniem Jego działania w życiu człowieka i dlatego są w pełni zrozumiałe tylko w kontekście historiozbawczym ${ }^{22}$. Spełnienie Bożej woli dokonuje się tylko wtedy, kiedy człowiek słucha tego, co Bóg mówi o sobie, a następnie realizuje Boże przykazania w swoim życiu ${ }^{23}$.

Czerpiące z inspiracji biblijnych homilijne głoszenie słowa Bożego nie polega na przekazywaniu kodeksu zachowań moralnych, lecz na budowaniu, posiadającej personalny i dialogiczny charakter, wiary. Odpowiedź, jakiej człowiek udziela Bogu podczas liturgii i poza nią, polega przede wszystkim na osobowej więzi ze Stwórcą. Bowiem, jak uczy Benedykt XVI, „, początku bycia chrześcijaninem nie ma etycznej, czy jakiejś wielkiej idei, ale natomiast spotkanie z wydarzeniem, z Osobą, która nadaje życiu nową perspektywę, a tym samym decydujące ukierunkowanie" (DC 1).

\section{Treść głoszonych zasad}

Papież Benedykt XVI w adhortacji apostolskiej Sacramentum Caritatis wskazuje na konieczność poprawienia jakości homilii, która ma za zadanie dopomagać pełnemu zrozumieniu oraz oddziaływaniu słowa Bożego na życie wiernych. Szczególna zachęta dotyczy głoszenia słowa Bożego ściśle powiązanego

z celebracją sakramentalną i z życiem wspólnoty tak, by słowo Boże było rzeczywistym wsparciem dla życia Kościoła. Należy mieć na uwadze katechetyczny i zachęcający cel homilii. [...] Treść do nich należy czerpać w sposób pewny z Magisterium w oparciu o cztery „filary” określone przez Katechizm Kościoła Katolickiego

22 L. Szewczyk, Zagadnienia moralne..., dz. cyt., s. 51.

23 M. Wróbel, Od lektury Słowa Bożego do chrześcijańskiego czynu - doświadczenie szkoły Słowa Bożego i lectio divina, „Zeszyty Naukowe KUL” 53 (2010) 3 (211), s. 21. 
i niedawno ogłoszone Kompendium, a więc: wyznanie wiary, celebracja misterium chrześcijańskiego, życie w Chrystusie, modlitwa chrześcijańska. (SCar 46)

Trzecia część Katechizmu Kościoła Katolickiego (1691-2557) mówiąca o życiu w Chrystusie przedstawia podstawowe zagadnienia moralne: godność osoby ludzkiej, wspólnotę ludzką, zbawienie Boże (prawo i łaska), dziesięć przykazań oraz przykazanie miłości Boga i człowieka. „Dziesięć przykazań, będąc wyrazem podstawowych powinności człowieka względem Boga i względem bliźniego, objawia w swojej istotnej treści poważne zobowiązania" (KKK 2072). Do życia moralnego, które jest związane z życiem liturgicznym i z niego czerpie moc, odnoszą się także przykazania kościelne. Obowiązujący charakter tych praw pozytywnych ma na celu „zagwarantowanie wiernym niezbędnego minimum ducha modlitwy i wysiłku moralnego we wzrastaniu miłości Boga i bliźniego" (KKK 2041).

Homilia powinna prowadzić do przemiany życia poszczególnych uczestników, pomagając w udzielaniu odpowiedzi wierzącym na usłyszane słowo Boże. Dlatego ma ona wskazywać na możliwe sposoby odpowiedzi na Boże wezwanie w codziennym życiu. Słuchacz powinien usłyszeć o tym, jak jego wiara ma być realizowana we współczesnym świecie, i musi wiedzieć, że Bóg postawił mu określone zadania oraz oczekuje na nie odpowiedzi. Odpowiedź ta realizuje się na trzech płaszczyznach ludzkiego życia: wiary, nawrócenia i miłości ${ }^{24}$. Homilia, która jest jedynie pouczeniem dotyczącym tekstu biblijnego, a nie zawiera jednocześnie nakłaniania, napominania i umacniania, nie spełnia swego zasadniczego zadania. Współczesne głoszenie Ewangelii musi polegać na starannym odczytaniu prawd objawionych, które wyrastają z niej w kontekście nowego świata, nowej sytuacji społecznej, nowych zagrożeń człowieka. To głoszenie powinno 
być przeniknięte nową interpretacją starych prawd. To poszczególne perykopy lekcjonarza za każdym razem sugerują homiliście i słuchaczowi konkretny, klarowny i aktualny moralny apel ${ }^{25}$.

Dyrektorium homiletyczne zaleca również korzystanie w wyborze problematyki moralnej z Katechizmu Kościoła Katolickiego. W aneksie do Dyrektorium powiązano

kerygmat czytań poszczególnych niedziel i świąt trzyletniego cyklu roku liturgicznego z wybranymi fragmentami katechizmu. Aneks ten jest więc przykładem łączenia orędzia tekstów świętych: biblijnych i liturgicznych z Tradycją i nauczaniem Nauczycielskiego Urzędu Kościoła. ${ }^{26}$

Kiedy homilista będzie korzystał z Katechizmu Kościoła Katolickiego, w ten sposób

może pomóc swoim słuchaczom w połączeniu słowa Bożego, wiary Kościoła, moralnych wymagań Ewangelii oraz ich duchowości osobistej i liturgicznej. (DH 160)

Homilista powinien skoncentrować się na jednym, zasadniczym problemie, choć może on być wewnętrznie złożony. Problem ten powinien wynikać bezpośrednio z kerygmatu tekstów świętych. Skoncentrowanie uwagi na jednym problemie uchroni homilistę przed skomplikowanym i niepotrzebnym rozszczepieniem myśli, a słuchaczom ułatwi zachowanie w pamięci istotnej treści homilii ${ }^{27}$. Zachęta

25 Z. Sideł, Pareneza homilijna..., dz.cyt., s. 154; W. Lechowicz, Jak głosić kazania o tematyce moralnej?, "Currenda” 153 (2003) 3, s. 438.

26 H. Sławiński, Znaczenie, geneza i struktura "Dyrektorium homiletycznego", „Polonia Sacra" 19 (2015) nr 3, s. 168.

27 S. Olejnik, Współczesna homilia w jej treści moralnej, „Homo Dei” 50 (1981) nr 4, s. 261. 
ta jest wsparta przestrogą papieża Franciszka, który uczy, że przepowiadanie słowa może być

niezrozumiałe ze względu na chaotyczność, brak logiki albo ponieważ jednocześnie podejmuje różne tematy. Dlatego innym niezbędnym zadaniem jest sprawienie, aby kazanie miało jedność tematyczną, jasny porządek i powiązanie między zdaniami, aby osoby mogły łatwo podążać za kaznodzieją i pojąć logikę jego wywodu. (EG 158)

\section{Konieczność zróżnicowanego uzasadniania głoszonych zasad}

Zagadnieniem fundamentalnym w głoszeniu zasad życia chrześcijańskiego jest uzasadnianie norm moralnych, bowiem koniecznym jest ukazywanie racji, dla których reguły postępowania obowiązują oraz dlaczego przestrzeganie ich jest konieczne. Uzasadnienie norm moralnych nie może naruszać wolności słuchacza, a jednocześnie powinno go przekonać do przyjęcia słowa Bożego i realizacji tego słowa we własnym życiu.

Uzasadnianie zaś polega na ukazywaniu racji przemawiających za przyjęciem głoszonych norm moralnych, racji świadczących o tym, że normy te są słuszne i obowiązujące. Wśród wielu sposobów argumentowania na rzecz głoszonych norm moralnych, w praktyce najczęściej stosowane bywa odwoływanie się do uznanego autorytetu, wskazywanie na wymogi struktury osoby ludzkiej i egzystencji chrześcijańskiej. ${ }^{28}$ 
Homilista, uzasadniając konieczność przyjęcia chrześcijańskiej moralności, może wskazać na pobudki o charakterze nadprzyrodzonym, jak na przykład miłość Boga czy osiągnięcie wiecznego zbawienia. Droga do zbawienia nie wiedzie przez realizowanie litery prawa, ale przez Boga, który daje człowiekowi przykład do naśladowania. Może również odwoływać się do pobudek naturalnych, wskazując,

że moralnym jest to, co człowieka rozwija, niemoralnym zaś to wszystko, co człowiekowi szkodzi. Warto w tym względzie odwołać się do objawienia biblijnego, które opisuje grzech człowieka przede wszystkim w kategoriach egzystencjalnych, jako nieszczęście człowieka. ${ }^{29}$

Wojciech Bołoz, odwołując się do psychologicznego opisu rozwoju moralnego człowieka, proponuje, by uzasadnianie głoszonych norm moralnych dopasować do mentalności słuchaczy. Wskazuje na cztery etapy rozwoju moralności uwarunkowane wiekiem i poziomem osobistej dojrzałości.

$\mathrm{Na}$ etapie moralności heteronomicznej (dzieciństwo i wczesna młodość) człowiek opiera się na autorytetach, którymi zazwyczaj są rodzice i nauczyciele, znane osoby publiczne, Pismo Święte i Kościół. Mocne powiązanie emocjonalne z autorytetem przejawia się także przez trwałe utożsamianie się z głoszonymi przez niego poglądami.

Na etapie moralności na poziomie prekonwencjonalnym człowiek szuka własnych kryteriów osobistego postępowania i oceny czynów innych ludzi. Często przemawia do niego tzw. złota zasada, czyli: „,cokolwiek chciałbyś, aby tobie czyniono, czyń innym”. Na tym etapie troska o siebie i swoje szczęście zachęca do unikania postępowania 
zagrożonego utratą wiecznego zbawienia. Mamy wówczas do czynienia $\mathrm{z}$ uzasadnianiem teologiczno-eschatologicznym ${ }^{30}$.

Kolejny etap cechuje się moralnością na poziomie konwencjonalnym, czyli zgodnością z zasadami grupy społecznej, do której się należy. Odwoływanie się do potrzeby partycypacji - zdaniem autora - jest stosunkowo mało obecne w przepowiadaniu słowa Bożego.

Ostatni etap (poziom postkonwencjonalny), to najwyższy etap rozwoju moralnego. Ci, którzy go osiągają, mają świadomość istnienia obiektywnych wartości i norm moralnych, które trzeba respektować. Taka moralność charakteryzuje

ludzi dojrzałych, posiadających wybrany przez siebie, spójny i zaakceptowany osobiście system wartości i norm. Ludzie na tym poziomie rozwoju moralnego potrafią uznać słuszne racje innych i dostrzegać ich potrzeby [...]. Są bowiem wrażliwi na godność człowieka i bronią jego praw niezależnie od jakości i etapu jego życia, gotowi są poświęcić wiele, aby dochodzić sprawiedliwości, ich celem jest budowanie królestwa Bożego. Te wartości do nich przemawiają i wyzwalają ich działanie. ${ }^{31}$

\section{Miejsce głoszenia zasad moralnych w przepowiadaniu homilijnym}

Dyrektorium homiletyczne w punktach 9-11, odwołując się do nauczania Kościoła (OWMR 65 i WLM 24), określa, czym jest homilia. Trzy kolejne punkty tego dokumentu opisują dynamikę homilii. W pierwszej jej części homilista mówi

30 W. Bołoz, Współczesne sposoby uzasadniania norm moralnych, w: Veritatem facientes. Księga pamiątkowa ku czci ks. prof. F. Greniuka, red. J. Nagórny, J. Wróbel, Lublin 1997, s. 361-374.

31 W. Bołoz, Współczesne przepowiadanie..., dz. cyt., s. 26. 
o czytaniach i modlitwach z celebracji w taki sposób, że ich znaczenie zostaje ukazane przez pryzmat śmierci i zmartwychwstania Pana [...]. Łącząc czytania z tajemnicą paschalną, rozważania mogą z powodzeniem odnosić się do nauk doktrynalnych lub moralnych, które zarysowują się w tekstach. (DH 12)

W drugiej części homilii powinno nastąpić przygotowanie wspólnoty do

celebrowania Eucharystii i do rozpoznania, że w tejże celebracji zgromadzeni naprawdę biorą udział w tajemnicy śmierci i zmartwychwstania Pana. (DH 13)

Trzecia, najkrótsza część, polega na podpowiedzi,

jak członkowie wspólnoty, przemienieni przez Eucharystię, mogą w swoim powszednim życiu wnieść Ewangelię w świat. Oczywiście, treść i kierunek tych zastosowań wynika z czytań biblijnych, ale homilista powinien także uwydatnić skutek samej Eucharystii, która wkrótce będzie celebrowana, oraz jej następstwa dla codziennego życia w błogosławionej nadziei na nierozdzielną komunię z Bogiem. (DH 14)

Najczęściej stosowanym w przepowiadaniu słowa Bożego w Polsce modelem homilii jest model egzystencjalno-dialogiczny. W części pierwszej kaznodzieja nawiązuje do życia słuchaczy i tam szuka konkretnego pytania, na które odpowiada zawarte w czytaniach słowo Boże. W części drugiej formułuje odpowiedź na postawione pytanie, odwołując się do autorytetu słowa Bożego. W trzeciej zaś ukazuje praktyczne wnioski, jakie wynikają z lektury Pisma Świętego. $\mathrm{W}$ ten sposób moralny imperatyw, wypływający z homilii, ukazany jest jako konsekwencja indykatywu zbawczego. Model ten oparty 
jest na schemacie: „doświadczenie życiowe - to mówi Pan - życie chrześcijańskie” ${ }^{32}$. To w części „życie chrześcijanina”, po zasugerowaniu odpowiedzi słowa Bożego na egzystencjalne pytanie, kaznodzieja formułuje praktyczne wnioski, jakie z owej odpowiedzi wynikają, biorąc pod uwagę grupę słuchaczy, do której przemawia. Na tym etapie słuchacz powinien uzyskać odpowiedź: jak ma swoim życiem uczcić Boga. W ten sposób imperatyw moralny, wypływający z homilii, zostaje ukazany jako konsekwencja indykatywu zbawczego, ukazanego na poprzednim etapie ${ }^{33}$. Przywołany egzystencjalno-dialogiczny model homilii, chociaż najczęściej stosowany w praktyce przepowiadania słowa Bożego w Polsce, zawiera - jak wykazał Henryk Sławiński - poważny mankament, jakim jest pominięcie mistagogicznego elementu przepowiadania homilijnego. Natomiast niezależnie od stosowanego modelu budowy homilii indykatyw zbawczy powinien poprzedzać imperatyw moralny, a sama treść powinna motywować do kształtowania codziennego życia zgodnie $\mathrm{z}$ wyznawaną wiarą ${ }^{34}$.

\section{Inne elementy formalne w głoszeniu zasad moralnych}

W głoszeniu zasad życia chrześcijańskiego należy posługiwać się językiem pozytywnym. Homilista powinien nie tyle przestrzegać przed niewłaściwymi postawami, ale raczej proponować to, co można robić lepiej. Postawa pozytywna pociąga, dlatego nie można

zatrzymywać się na narzekaniu, na żaleniu się, na krytyce lub na wyrzutach sumienia. Ponadto, kazanie pozytywne daje zawsze

32 G. Siwek, Przepowiadać skuteczniej. Elementy retoryki kaznodziejskiej, Kraków 1992, s. 76.

33 L. Szewczyk, Zagadnienia moralne..., dz. cyt., s. 56.

34 H. Sławiński, Potrzeba urozmaicenia modelu homilii, „Studia Włoclawskie” 11 (2009), s. $95,96$. 
nadzieję, kieruje ku przyszłości, nie czyni nas więźniami rzeczy negatywnych. (EG 159)

Miłość do głoszonej prawdy powinna się spotkać z wielkim szacunkiem dla słuchaczy. $\mathrm{Na}$ ambonie nie powinny występować wypowiedzi „natrętnie moralizatorskie, formułowane z wielką pewnością siebie, z pozycji wyższości w stylu napuszonym i pretensjonalnym" 35 .

Homilista, głosząc zasady życia chrześcijańskiego, powinien posługiwać się mową, która angażuje wewnętrznie słuchaczy. Wskazane jest stosowanie szerokiej argumentacji, odwołującej się do sfery intelektualnej, emocjonalnej i wolitywnej człowieka. Argumenty powinny być przedstawiane w taki sposób, aby przekonać słuchacza, że posłuszeństwo wymogom moralnym i rozwiązaniom proponowanym przez homilistę służy jego wiecznemu i doczesnemu dobru. Wymagania należy formułować w sposób pozytywny, dostosowany do słuchaczy i na miarę ich możliwości ${ }^{36}$.

Papież Franciszek przestrzega, że przepowiadanie czysto moralizujące, doktrynerskie bądź sprowadzające się w całości do wykładu z egzegezy biblijnej skutkuje osłabieniem tego porozumienia serc, które powinno urzeczywistniać się w homilii i które ma nieomal charakter sakramentalny, ponieważ wiara rodzi się ze słuchania (por. EG 142). (DH 6)

\section{Lectio divina jako pomoc w przygotowaniu do głoszenia zasad życia chrześcijańskiego}

Analiza wyników prowadzonych badań nad treścią homilii pozwala wskazać niedociągnięcia w głoszeniu zasad życia chrześcijańskiego.

35 S. Olejnik, Współczesna homilia..., dz. cyt., s. 262.

36 W. Lechowicz, Jak głosić kazania..., dz. cyt., s. 441-443. 
Do najważniejszych z nich należą: niedostateczne uwzględnienie chrystocentrycznego wymiar parenezy, brak właściwych proporcji między kerygmatem zbawczym i imperatywem moralnym, niewystarczające wskazywanie na paschalny oraz pneumahagijny wymiar chrześcijańskiej moralności, osłabione budowanie wezwań moralnych na fundamencie mistagogii ${ }^{37}$. Tymczasem to $\mathrm{z}$ właściwie przeżytego momentu mistagogicznego wypływa moment etyczny, czyli właściwa postawa życiowa słuchacza, którą wyrabia w życiu ${ }^{38}$.

W wielu homiliach dostrzega się formułowanie ogólnikowych i nieuzasadnionych napomnień, brak uwzględniania wieloznaczności ludzkiego życia czy straszenie słuchaczy ${ }^{39}$. Wciąż często występuje w przepowiadaniu homilijnym zjawisko moralizowania, które przejawia się w tym, że homilista rości sobie pretensję do zbawiania lub uświęcania człowieka ${ }^{40}$. Tymczasem być chrześcijaninem oznacza w pierwszym rzędzie być dzieckiem Bożym, nowym stworzeniem, esse christianum, a moralizatorstwo wielu homilii polega na mówieniu o christianum agere, bez wskazania najpierw na christianum esse ${ }^{41}$.

Powyższym niedociągnięciom można zaradzić, między innymi przez właściwe przygotowanie każdej homilii. Dyrektorium homiletyczne proponuje lectio divina jako metodę przygotowania homilii. Metoda ta była zalecana przez ojców Kościoła, a ostatnio przez papieża Benedykta XVI (DV 87) i papieża Franciszka (EG 152) ${ }^{42}$. Słowo Boże, gdy jest czytane, medytowane, modlitewnie kontemplowane, przemienia nasze codzienne działanie i życie, to słowo jest w ustach dla lektury (lectio), w sercu dla medytacji i modlitwy (meditatio i oratio), w czynach dla kontemplacji (contemplatio) i akcji

37 Z. Sideł, Pareneza homilijna w polskim..., dz. cyt., s. 154.

38 J. Swędrowski, Kształtowanie postaw moralnych w przekazie kaznodziejskim, "Studia Loviciensia" 6 (2004), s. 246.

39 Z. Sideł, Pareneza homilijna w polskim..., dz. cyt., s. 154.

40 J. Kudasiewicz, H. Witczyk, Chrystus zbawia w sakramentach, Kielce 2001, s. 6n.

41 H. Sławiński, Przepowiadanie Chrystusowego krzyża, Warszawa 1997, s. 261n.

42 Tenże, Znaczenie, geneza i struktura..., dz. cyt., s. 168. 
$(\text { actio })^{43}$. Praktyka lectio divina sprzyja rozwijaniu życia duchowego homilisty, kieruje jego uwagę na prawdy objawione i pomaga zestawić z nimi osobiste życie, dostarcza pojęć i myśli, które służą za podstawę do pracy nad sobą ${ }^{44}$.

Warto też przypomnieć, że lectio divina w swojej dynamice nie kończy się, dopóki nie doprowadzi do działania (actio), sprawiającego, że życie wierzącego staje się darem dla innych w miłości. (VD 87)

\section{Zakończenie: głoszenie i świadectwo}

Akceptacja zasad życia chrześcijańskiego głoszonych przez homilistę, a następnie ich realizacja w codziennym postępowaniu, w dużej mierze uzależniona jest od zaufania, jakim cieszy się on u słuchaczy.

Im kaznodzieja cieszy się większym autorytetem i szacunkiem, tym większe są szanse na przekonanie słuchaczy do głoszonych treści. W kwestiach moralnych zasadniczą rolę odgrywa też świadectwo życia kaznodziei. Pierwszym słowem, które kaznodzieja kieruje do wiernych, jest jego własne życie! ${ }^{45}$.

Rozwiązania, jakie homilista proponuje słuchaczom, powinny być wyrazem jego pogłębionej wiedzy teologicznej, świadectwem osobistych przemyśleń, ale nade wszystko rozwiązań moralnych podejmowanych

43 H. Witczyk, Lectio divina droga do kontemplacji Jezusa - Słowa Boga, w: Kontemplacja Chrystusa - Ikony miłosiernego Ojca, red. J. Kudasiewicz, H. Witczyk, Kielce 2002, s. 250n.

$44 \mathrm{H}$. Wejman, Wartość lectio divina dla rozwoju duchowego człowieka, w: Sentire cum Ecclesia, red. P. Podeszwa, Gniezno 2004, s. 477-486.

45 W. Lechowicz, Jak głosić kazania..., dz. cyt., s. 441. 
w jego własnym życiu. Osobiste świadectwo głoszącego uwierzytelnia słuszność chrześcijańskich wskazań moralnych oraz ma poważną szansę skutecznego oddziaływania na słuchaczy.

Pomoże im w wytworzeniu głębokiego przekonania i osobistego zaangażowania w dokonaniu refleksji moralnej nad sobą i w realizowaniu chrześcijańskich wymagań moralnych w życiu. ${ }^{46}$

\section{Chrystocentryczne głoszenie zasad życia chrześcijańskiego}

\section{Streszczenie}

Ambona jest miejscem przekazywania treści wiary oraz prowadzenia słuchaczy do udziału w tajemnicy Chrystusa, co powinno być związane z wewnętrzną przemianą słuchaczy słowa Bożego. Słuchacz powinien dowiedzieć się o tym, jak może realizować swoją wiarę we współczesnym świecie. Opracowanie podejmuje próbę odpowiedzi na pytania o chrystocentryzm przepowiadania zasad życia chrześcijańskiego i jego biblijne inspiracje. Refleksja dotyczy również zasadniczych treści i formy oraz wskazuje pewne niedociągnięcia współczesnego głoszenia zasad życia chrześcijańskiego.

Słowa kluczowe

Chrystocentryzm, zasady życia chrześcijańskiego

\section{Christocentric preaching the rules of Christian life}

Summary

A pulpit is a place of conveying the content of the faith and introducing listeners to the mystery of Christ, which should be related to an internal transformation of listeners of the Word of God. A listener should learn how to put his/her faith into practice in the contemporary world. The paper tries to answer questions

46 S. Olejnik, Współczesna homilia..., dz. cyt., s. 262n. 
concerning christocentrism of preaching, the rules of Christian life, and its biblical inspirations. The reflection concerns as well the major content and a form. It points at certain deficiencies of the contemporary preaching the rules of Christian life.

Keywords

Christocentrism, the rules of Christian life

\section{Bibliografia}

Bołoz W., Współczesne przepowiadanie moralne i potrzeba uzasadnienia i motywacji, „Homo Dei” 78 (2008) nr 1 (286), s. 17-29.

Bołoz W., Współczesne sposoby uzasadniania norm moralnych, w: Veritatem facientes. Księga pamiątkowa ku czci ks. prof. F. Greniuka, red. J. Nagórny, J. Wróbel, Lublin 1997, s. 361-374.

Chmielewski M., Chrystocentryzm, w: Leksykon duchowości katolickiej, red. tenże, Lublin-Kraków 2002, s. 121-123.

Jędrzejewski S., Moralne implikacje przymierza, „Seminare” 29 (2011), s. 7-19.

Kudasiewicz J., Cechy specyficzne etosu biblijnego, w: Chrześcijańska duchowość, red. B. Bejze, Warszawa 1981, s. 61-88.

Lechowicz W., Jak głosić kazania o tematyce moralnej?, "Currenda” 153 (2003) 3, s. 438-444.

Olejnik S., Współczesna homilia w jej treści moralnej, „Homo Dei” 50 (1981) nr 4, s. 258-264.

Papieska Komisja Biblijna, Interpretacja Biblii w Kościele. Dokument Papieskiej Komisji Biblijnej z komentarzem biblistów polskich, red. R. Rubinkiewicz, Warszawa 1999.

Sideł Z., Pareneza homilijna w polskim przepowiadaniu posoborowym. Studium homiletyczne w świetle "Kazań świętokrzyskich" okresu Wielkiego Postu, mps, rozprawa doktorska, Biblioteka KUL, Lublin 2013.

Sławiński H., Potrzeba urozmaicenia modelu homilii, „,Studia Włoclawskie” 11 (2009), s. 90-97

Sławiński H., Znaczenie, geneza i struktura "Dyrektorium homiletycznego”, „Polonia Sacra" 19 (2015) nr 3, s. 155-176.

Stachowiak L., Wartości etyczne tradycji o przymierzu, w: Biblia - księga życia Ludu Bożego, red. S. Łach, M. Filipiak, Lublin 1980, s. 19-27. 
Swędrowski J., Kształtowanie postaw moralnych w przekazie kaznodziejskim, „Studia Loviciensia" 6 (2004), s. 239-247.

Szewczyk L., Chrystocentryzm w teorii i praktyce przepowiadania słowa Bożego, „Studia Pastoralne" 7 (2011), s. 310-319.

Szewczyk L., Treść przepowiadania kaznodziejskiego według adhortacji apostolskiej „Evangelii Gaudium”, „Studia Pastoralne” 10 (2014), s. 341-350.

Szewczyk L., Zagadnienia moralne w wypowiedzi kaznodziejskiej, „Śląskie Studia Historyczno-Teologiczne" 37 (2004) z. 2, s. 58-57.

Twardy J., Chrystocentryzm w kaznodziejskiej posłudze słowa, „Śląskie Studia Historyczno-Teologiczne" 40 (2007) z. 1, s. 50-64. 